\title{
DIMENSIONALITY OF INTRA-ORGANIZA- TIONAL CONFLICT AND THE CHALLENGES FOR HUMAN RESOURCE MANAGEMENT IN SMALL AND MEDIUM SCALE ENTERPRISES IN NIGERIA
}

\section{- Samuel Remi}

\begin{abstract}
There is a reasonable level of acceptance amongst policy makers, academia and international development agencies of the criticality of Small and Medium-sized Enterprises (SMEs) as important agents of development particularly in employment and income generation and the provision of goods and services. Successive governments in Nigeria continue to promote policies and agendas targeted to raise the competitiveness of the sector as part of the diversification of the economy and promote foreign direct investment (FDI). These efforts are yet to manifest in any significant reduction in importation of basic goods as well as double-digit unemployment rate. Several studies have focused on aspects of SME's performance with a sparse attention to the criticality of the impacts of conflict in the performance of the organisations leading to a wide gap in knowledge as to whether a conflict situation actually occurs in the SMEs, and if they do, how do they manifest? What are the impacts on performance and how effective are the administrative tools for managing them? This study attempts to bridge this gap. We adopt a survey method using a sample of 224 employees across a spectrum of industries located in Lagos, Ogun and Kwara States of the Federation of the Republic of Nigeria. While the prevalence of conflict was established in the study amongst the employees, compensation, reward and performance rating issues are most frequent sources of the conflict with behavioural manifestation including productivity scale down, battering the reputation and image of the employers as well as discouraging potential applicants. The study also found that most of the administrative tools to manage conflict are not considered very effective while a variation in the gender awareness to conflict was observed at the level of statistical significance. The study recommends conflict minimization strategies through a proper goal definition, conflict management skill upgrades with training, open communication, fair reward and compensation system. The risk of of the error occurrence is examined from the accountants' perspective. For this purpose, a questionnaire survey was used for data collection focusing on areas that are considered to be the most important by the accountants and the areas which are the most problematic.
\end{abstract}

Keywords: intra-organizational relationships, conflict, small and medium scale enterprises, competitiveness, buman resource management, Nigeria

JEL Classification: M10, M11, M12 


\section{INTRODUCTION}

Researchers and managers have focused on several aspects of the Small and Medium Scale Enterprises (hereinafter refers to as SMEs) given the global promotion of the sector by policy makers and international agencies as agents of economic growth and development in terms of production of goods, services and employment generation. Nigeria is therefore not left behind in this quest for a viable SME subsector through the promotion of foreign direct investments, formulation of investment friendly policies through facilitation of business registration, land availability, tax incentives amongst other initiatives to boost the productive capacity of the SMEs. Despite these apparent incentives, the country continues to rely on a massive importation of goods and services and low competitiveness of the sector. According to Ahmedova (2015) citing the annual report of Bulgarian Small and Medium Enterprise Promotion Agency, a favourable business environment is the main aspect that impacts upon the enterprise competitiveness. Such an environment involves the government, the quality of the institutions, the infrastructure, technological and innovation development, and the quality of the human resources. The sphere of conflict seemed to be either neglected or inconsequential.

However, conflict is one of the most researched areas of modern phenomena arising partly from the dominant dysfunctional paradigm of conflict in social, behavioural and political sciences particularly those expressed in terms of war, protests, demonstrations, strikes, etc. We found out at www.questia.com that the library listed 224,235 articles in periodicals, 77,785 in books and 517 in encyclopaedia (20.04.2016), which underscore the research resources assigned to the study area. Despite such extensive probe over decades, the subject still draws continuous research attention both regarding academics and practice principally because of the detestable and dysfunctional notion of conflict. Although, there are recent propositions that have asserted that some level of conflict is indeed positive at the micro level (Edwin, 2002; Hammed \& Ayantunji, 2002). Awan \& Saeed (2015) stated that to a certain degree, a managed conflict is functional and important for organisational development while Bourgeois (1998) maintained that conflict at senior and top management levels of organizations is inevitable and usually valuable. Creating a conflict free environment while impracticable should not be the core management objective but in establishing procedures and systems capable of recognising the problem it faces and establish effective ways of managing them (Nightingale, 1974). Furthermore, according to Henry (2009) conflict creates the productive force that energises members of an organisation to increase their knowledge and skills and contribute to organisational innovation and productivity. At the micro level of analysis, some contemporary authors (i.e., Jones et al. 2000; Adomi \& Anie, 2005; Awan $\&$ Saeed, 2015) contend that conflict is an inevitable part of organisational life having both positive and negative potential outcomes depending on how it is managed.

While the process of achieving these positive results have not been fully articulated, it has been agreed that the unmanaged conflict portends danger, as this is capable of promoting dysfunctional behaviours amongst employees that can lead to consequential loss such as low productivity, high wastes and high attrition rates.

This study is not premised on functionality or otherwise of conflict we rather attempt to explore the implications of its dimensionality and the effectiveness of management strategies in the small and medium-scale enterprises (SMEs), giving the importance of the subsector as a ma- 
jor vehicle for economic development. The United Nations Industrial Development Organisation (UNIDO), for example, estimated that $90 \%$ of enterprises are SMEs that account for about $80 \%$ of employments in the world while the Central Bank of Nigeria in its Financial System Strategy (FSS 2020) estimated that $96 \%$ of Nigerian business enterprises are categorised as SMEs [representing about $90 \%$ of the manufacturing/business sector] but noted that the subsector contributes less than $1 \%$ of the Gross Domestic Product (GDP) compared with $40 \%$ in Asian countries and $50 \%$ in the US and Europe. Given the governmental policy focus on the SMEs as the engine for economic growth, the poor result raises the key question about the nature of the factors inhibiting the sectors performance. While a number of studies have explored the question of SMEs performance and problems in Nigeria (Agwu \& Emeti, 2014), there is a wide gap in knowledge of conflict within the SMEs as literature search shows lack of focus at this level of analysis. For example, the search for intra-organisational conflict at ww.questia.com returned zero result for SMEs, which underscore the importance of this study. One is likely to view this observed research neglect as major academic oversight given the dare need for a vibrant SME sub-sector which constitutes strategic foci of industrial growth and economic development in Nigeria and part of the sub-Saharan Africa.

According to Bannok (2005), the reasons why people are interested in SMEs may have to do with the juxtaposition of its perceived desirability and vulnerability. They are desirable because they promote competition and employment and a few of them innovate and grow into large firms that potentially generate even more of these things. However, the high incidence of failure amongst the SMEs in Nigeria to achieve significant performance breakout calls for a new probe into the internal dynamics of the organizations, especially those factors that affect their internal cohesion to achieve optimal performance. The role of intra-organizational conflict is suspected as one of the key variables in explaining the problems.

This study sees the intra-organizational conflict as a form of dissonance that results from the dynamics of social interactions within an organization, which has space, time, and control dimensionality. It draws from the contingency conflict model as its theoretical framework, which essentially recognises dynamic behavioural responses to a conflict interaction. These may be related to personal characteristics such as sex, age, or personality. A pivotal role is supervisory skills to identify and manage conflict situations in their teams. The questions are in what forms does the conflict manifest in the SMEs studies and whether managers have adequate procedures for conflict resolution in place. Are employees fully aware of the conflict resolution mechanisms available to them? Are they encouraged to openly discuss conflict situations with their managers? Within the limitation of space and time, this study will attempt to find out whether intra -organizational conflicts have a significant impact on employees' behaviour and performance and how effectively do available institutional administrative tools for managing them meet their expectations? The answers to some of these questions will be valuable to managers and investors in the sector who are desirous of enhancing performance and profitability.

Consequently, the objective of this study is to provide new information on the work environment in the SMEs, particularly the forms, manifestation and management of intra-organizational conflict and how they are likely to impact on performance and human resource management system. If this knowledge is well-harnessed, this will improve employees' behaviours, performance effectiveness and the competitiveness of the organizations. 


\section{LITERATURE REVIEW}

Research has led to different distinctions and recognition of various levels of conflict (Rahim, 2002). Some analysis distinguished between macro and micro levels while the term conflict itself has come to mean a different thing to different people. In this realm, the term remains a rather fuzzy theoretical paradigm in sociological thinking (Rossel, 2013). Conflict is generally used in at least three important meanings: firstly, to summarize the theoretical tradition in sociological theory, which deals with conflict, power, domination and social change, exemplified by the authors like Karl Marx and Max Weber. Secondly, it is applied to denote the analysis and explanation of social conflicts in different sociological paradigms and in other behavioural sciences. Finally, it also applies to the substantive research on power structures, domination, conflict, and change but the early class dynamics gained prominence through the work of Karl Marx for decades. Generally, conflict has been used in the literature to denote one or combination of the following:

1. Antecedent conditions of competitive behaviours in which the case conflict reflects scarcity of resources or policy differences;

2. Affective states of the individuals involved in the conflict such as their expression in stress, tension, hostility or anxiety, etc.

3. Cognitive states of the individual actor in the conflict such as their perception or awareness or conflicting situation; and

4. Finally, conflicting behaviour ranging from passive resistance to overt aggression.

Given the broad range of the factors that may be considered to be conflicting in an organization, the antecedent implications may actually be more devastating than originally believed and this paper joins other authors to argue that if the conflict is not managed properly, it may promote unintended negative consequences which could impact both individual and organizational performance. For instance, employees that experience high incidence of conflict are less likely to be motivated and without proper management may actually take self-help options or exit. In the case of high performing or competent individuals, the organization may find it difficult or more costly to replace them.

In this regard, what seems most obvious from the literature is a consensus that all human relations may be viewed as interlaced by two closely related processes - the conflict and the integrative. According to Rahim (2001), conflict can be classified on the basis of the antecedent conditions that lead to it, which may originate from a number of sources, such as tasks, values, goals, and so on. A brief description of this classification amongst others include (1) affective conflict, which according to Pelled, Eisenhardt, \& Xin, (1999) is a condition in which group members have interpersonal clashes characterized by anger, frustration, and other negative feelings; and (2) substantive conflict that occurs when two or more organisational members disagree on their task or content issues. (3) Conflict of interest occurs when a party sharing the same understanding of a situation prefers different and somewhat incompatible outcomes like those involving distribution of scarce resources or a decision to share the work of solving it (Druckman \& Zechmeister, 1973); and lastly, (4) the goal conflict, which occurs when a preferred outcome or an end-state of two social entities is inconsistent. In rare cases, "it may involve divergent prefer- 
ences over all of the decision outcomes, constituting a zero-sum game" (Cosier \& Rose, 1977)

Furthermore, review of definitions and context of intra-organisational conflict shows that it takes place within four contexts, which may be overlapping. These are (1) the vertical conflict that occurs between levels in an organisation such as superior-subordinate conflict; (2) the horizontal level between departments, groups and employees at the same level, typically involving resource control and competition. Other qualitative research also include task versus relationship-related conflict that is predicated upon differences in outcome variables, such as team satisfaction (Jehn, 1995), performance, (De Dreu \& Weingart, 2003) and innovation (Lovelace, Shapiro, \& Weingart, 2001), and (3) the role conflict, which is a variant of intra-organisational conflict often arising from ambiguity in role definitions, role inter-dependency and lastly, (4) line-staff conflict, which reflects differences in values, beliefs and individual characteristics and approach. The importance of conflict classification becomes imperative because the effectiveness of managing it requires proper understanding of the nature and characteristics of the particular incident. For example, a one-fit-for-all strategy may unlikely be effective. Consequently, this knowledge will be helpful in designing and implementing effective conflict management strategies (Gayle et al., 1994; LaFrance et al., 1997; Tinsley, 2001).

\section{Design}

The study is designed to investigate the forms and dimensions of intra-organizational conflict and the effectiveness of the conflict management strategies, particularly how they impact on the human resource management system in the SMEs using the survey method. To operationalize the classification of the organisations, we adopt the Central Bank of Nigeria definition of SMEs to include business enterprises and services with turnover of less than one hundred million Nigerian Naira (less than \$500,000 USD) and employing less than three hundred employees, however, generally falls within some of applied definitions of SMEs in Europe. The European Commission and many member states, including the UK, define SMEs as those with fewer than 250 employees. The United States uses 499 employees as the overall threshold for large firms, Japan (299 employees) for manufacturing and (99 employees) for wholesale distribution and retail distribution and 49 employees for other services (Bannock, 2005).

The primary research tool is based on the quantitative method adopting a questionnaire format that first seeks to establish the personal background information of respondents such as age, gender, function, education and management level. Thereafter, we defined 14 conflict variables into a Likert-scale typology seeking first, to establish the prevalence followed by their perceived significances. To establish the occurrence of the conflict variables, we use a frequency scale of (1) never, to (5) always as well as the significance of each of the variables on the five-significance scale from (1) highly insignificant to (5) highly significant. The next section seeks to establish whether an unresolved conflict has the impact on employees' performance and the behavioural manifestation of the defined variables on a frequency scale of (1) never to (4) most of the time. The last section seeks to find out whether employees are familiar with conflict management tools and systems and to evaluate their effectiveness on an effectiveness scale of (1) highly ineffective to (5) highly effective. 


\section{OBJECTIVE AND METHODS}

We issued 400 questionnaires randomly to employees of SMEs in Lagos, Ogun, Oyo and Kwara States of Federal Republic of Nigeria, which are situated along the commercial corridor of south western axis of Nigeria using the www.businesslist.com.ng classifications. The return rate for the questionnaires was $56 \%$ (i.e., 224) properly completed and formed the basis for this study analysis while in terms of ownership of the companies, $35 \%$ were foreign (joint-ventures) and 65\% Nigerian. The chart in Figure I below shows the distribution list and return rate of the questionnaires by sectors of the SMEs.

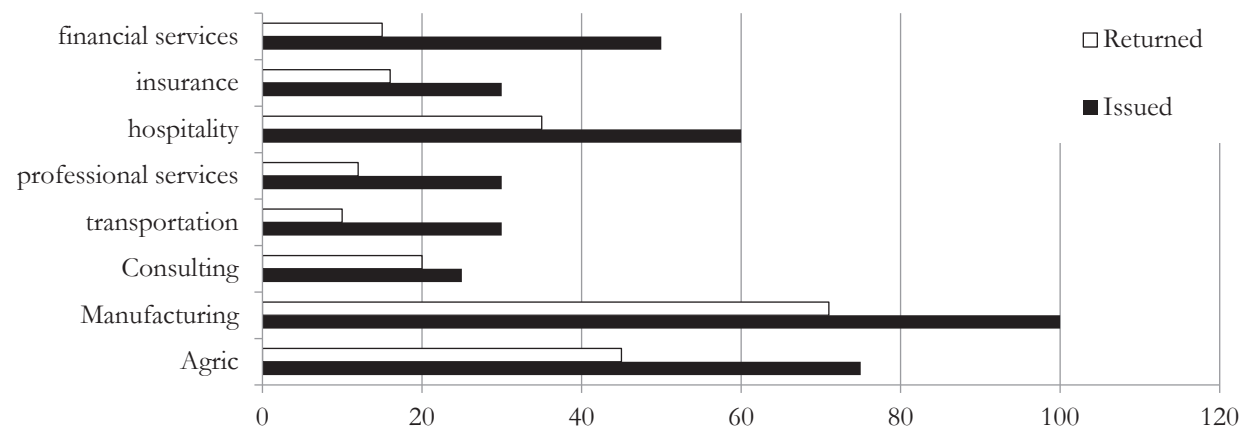

Fig. 1 - Sectorial distribution of questionnaires: Source: Field survey 2016.

The sample data shows that $20.1 \%$ of respondents were from agricultural sector, $31.7 \%$ from manufacturing, consulting services $(8.9 \%)$, transportation $(4.5 \%)$, professional services $(5.4 \%)$, hospitality (15.6\%), insurance $(7.1 \%)$, and financial services $(6.7 \%)$. The background variables of respondents are shown in Table 1.

Tab. 1 - Showing background characteristics of respondents. Source study: survey

\begin{tabular}{|l|l|l|l|l|l|}
\hline \multicolumn{2}{|l|}{} & $\begin{array}{l}\text { Frequency } \\
\text { N=244 }\end{array}$ & Percent & $\begin{array}{l}\text { Valid } \\
\text { Percent }\end{array}$ & $\begin{array}{l}\text { Cummulative } \\
\text { Percent }\end{array}$ \\
\hline \multirow{4}{*}{ GENDER } & Male & 136 & 60.7 & 60.7 & 60.7 \\
\cline { 2 - 7 } & Female & 88 & 39.3 & 39.3 & 100 \\
\hline \multirow{5}{*}{ FUNCTION } & Engineering & 9 & 4 & 4 & 4 \\
\cline { 2 - 7 } & Marketing & 40 & 17.9 & 17.9 & 21.9 \\
\cline { 2 - 7 } & $\begin{array}{l}\text { HRM/Administra- } \\
\text { tion }\end{array}$ & 63 & 28.1 & 28.1 & 50 \\
\cline { 2 - 7 } & Operations & 63 & 28.1 & 28.1 & 78.1 \\
\cline { 2 - 7 } & Manufacturing & 7 & 3.1 & 3.1 & 81.3 \\
\cline { 2 - 6 } & Finance & 42 & 18.8 & 18.8 & 100 \\
\hline
\end{tabular}




\begin{tabular}{|c|c|c|c|c|c|}
\hline \multirow{4}{*}{$\begin{array}{l}\text { LENGTH OF } \\
\text { SERVICE }\end{array}$} & Below 5 Years & 41 & 18.3 & 18.3 & 18.3 \\
\hline & 6 to 10 years & 110 & 49.1 & 49.1 & 67.4 \\
\hline & 11 to 15 years & 65 & 29 & 29 & 96.4 \\
\hline & 16 to 20 years & 8 & 3.6 & 3.6 & 100 \\
\hline \multirow{3}{*}{ AGE } & 25 to 35 years & 157 & 70.1 & 70.1 & 70.1 \\
\hline & 36 to 45 years & 57 & 25.4 & 25.4 & 95.5 \\
\hline & 46 to 55 years & 10 & 4.5 & 4.5 & 100 \\
\hline \multirow{4}{*}{$\begin{array}{l}\text { MANAGE- } \\
\text { MENT LEVEL }\end{array}$} & Junior & 56 & 25 & 25 & 25 \\
\hline & Supervisor & 106 & 47.3 & 47.3 & 72.3 \\
\hline & Assistant Manager & 54 & 24.1 & 24.1 & 96.4 \\
\hline & Manager & 8 & 3.6 & 3.6 & 100 \\
\hline \multirow{4}{*}{$\begin{array}{l}\text { HIGHEST } \\
\text { QUALIFICA- } \\
\text { TIONS }\end{array}$} & Diploma & 105 & 46.9 & 46.9 & 46.9 \\
\hline & First Degree & 112 & 50 & 50 & 96.9 \\
\hline & $\begin{array}{l}\text { Postgraduate Di- } \\
\text { ploma }\end{array}$ & 1 & 0.4 & 0.4 & 97.3 \\
\hline & Masters & 6 & 27 & 2.7 & 100 \\
\hline
\end{tabular}

The table shows that distribution by gender consists of $60.7 \%$ males and $39.3 \%$ females. While functional distribution of respondents show that $4 \%$ work in engineering, $17.9 \%$ in sales and marketing, human resource and administration (28.1\%), operations including farm $28.1 \%$, manufacturing 3.1\% finance including banking and auditing 18.8\%. Other background information includes the length of service, age, level and qualifications are also detailed in the table. It is interesting actually to find out that about $50 \%$ of the sample population has a first-degree certificate with a further $7 \%$ with postgraduate qualifications. The lack of trained womanpower may therefore no longer be counted as serious challenges to the SMEs, particularly in the environment of high unemployment rates not mentioning skills and employability of the graduates.

\section{Data Analysis}

The data obtained were analysed with the aid of IBM Statistical Package for Social Sciences (SPSS 21) using descriptive statistics, i.e. percentile for analysing the responses as well as Levene's test of equality of variance. Levene's test is an inferential statistic used to assess the equality of variances for a variable calculated for two or more groups. Some common statistical procedures assume that variances of the populations from which different samples are drawn are equal. Levene's test assesses this assumption. It tests the null hypothesis that the population variances are equal (called homogeneity of variance or homoscedasticity). If the resulting p-value of Levene's test is less than some significance level (typically 0.05), the obtained differences in sample variances are unlikely to have occurred based on random sampling from a population with equal variances. Thus, the null hypothesis of equal variances is rejected and it is concluded that there is a difference between the variances in the population. 


\section{RESULTS}

We adopt both graphic and tabular presentation of the study data for ease of reading and understanding. Table 1 above shows the background profile of respondents, which include their gender, function, and length of service, age, management level and educational qualifications. In Table 2, we present the data relating to frequency of causes of intra-organizational conflict while in Table 3, we show the perceived significance of each of those conflict variables. Table 4, shows the frequency of responses for assessment of effectiveness of the conflict management tools/ systems. To show whether all employees react the same way to the conflict sources, we present the Levenes test of equality for gender reactions to the conflict variables as shown in Table 5, while Table 6 shows the Levene's test of equality of variances in the behavioural manifestations to these conflict variables by gender.

Tab. 2 - Frequency of response to a research question of what the causes of intra-organizational conflict are. Source: Field survey 2016

\begin{tabular}{|c|c|c|c|c|c|c|}
\hline \multicolumn{7}{|c|}{$\begin{array}{l}\text { Frequency Table of intra-organizational cor } \\
\text { Total: } 224 \text { (100); Cummulative } \%: 100 \%\end{array}$} \\
\hline & Variable & Never & Rarely & $\begin{array}{l}\text { Some of } \\
\text { the times }\end{array}$ & Often & Always \\
\hline 1 & Goal conflict & $2(0.9)$ & $4(1.8)$ & $106(47.3)$ & $112(50.0)$ & $0(0)$ \\
\hline 2 & Rejection of ideas & $5(2.2)$ & $14(6.3)$ & $96(42.9)$ & $53(23.7)$ & $56(25)$ \\
\hline 3 & unclear tasks & $0(0)$ & $7(3.1)$ & $53(23.7)$ & $112(50.0)$ & $52(23.2)$ \\
\hline 4 & Undefined work expectations & $3(1.3)$ & $6(2.7)$ & $110(49.1)$ & $50(22.3)$ & $55(24.6)$ \\
\hline 5 & Work overload & $0(0)$ & $0(0)$ & $3(1.3)$ & $112(50)$ & $109(48.7)$ \\
\hline 6 & Salary Dissatisfaction & $0(0)$ & $0(0)$ & $0(0)$ & $0(0)$ & $224(100)$ \\
\hline 7 & Poor communication & $0(0)$ & $0(0)$ & $112(50.0)$ & $56(25.0)$ & $56(25.0)$ \\
\hline 8 & personality differences & $0(0)$ & $56(25.0)$ & $56(25.0)$ & $112(50.0)$ & $0(0)$ \\
\hline 9 & Abuse of authority & $6(2.7)$ & $2(0.9)$ & $160(71.4)$ & $56(25.0)$ & $0(0)$ \\
\hline 10 & Scarce resource allocation & $0(0)$ & $7(3.1)$ & $160(71.4)$ & $57(25.4)$ & $0(0)$ \\
\hline 11 & Poor compensation & $0(0)$ & $0(0)$ & $3(1.3)$ & $58(25.9)$ & $163(72.8)$ \\
\hline 12 & Performance appraisals & $0(0)$ & $0(0)$ & $0(0)$ & 60 & $164(73.2)$ \\
\hline 13 & Work interruptions & $1(0.4)$ & $5(2.2)$ & $162(72.3)$ & $0(0)$ & $56(25.0)$ \\
\hline 14 & Delayed promotion & $1(0.4)$ & $1(0.4)$ & $3(1.3)$ & $111(49.6)$ & $108(48.2)$ \\
\hline
\end{tabular}


Tab. 3 - Frequency of responses to a research question of how significant you perceive each of the identified sources of conflict. Source: Field survey 2016

\begin{tabular}{|c|c|c|c|c|c|c|}
\hline \multicolumn{7}{|c|}{$\begin{array}{l}\text { Frequency distribution of Significance of } \\
\text { Total: } 224 \text { (100); Cummulative \%: 100\% }\end{array}$} \\
\hline & Variable & $\begin{array}{l}\text { Highly } \\
\text { Insignifi- } \\
\text { cant }\end{array}$ & $\begin{array}{l}\text { Insignifi- } \\
\text { cant }\end{array}$ & Significant & $\begin{array}{l}\text { Very sig- } \\
\text { nificant }\end{array}$ & $\begin{array}{l}\text { Highly } \\
\text { significant }\end{array}$ \\
\hline 1 & Goal conflict & $0(0.00)$ & $3(1.34)$ & $109(48.66)$ & $98(43.75)$ & $14(6.25)$ \\
\hline 2 & Rejection of ideas & $0(0.00)$ & $1(0.45)$ & $2(0.89)$ & $111(49.55)$ & $110(49.11)$ \\
\hline 3 & unclear tasks & $0(0.00)$ & $3(1.34))$ & $54(24.11)$ & $111(49.55)$ & $56(25.00)$ \\
\hline 4 & $\begin{array}{l}\text { Undefined work } \\
\text { expectations }\end{array}$ & $1(0.45)$ & $2(0.89)$ & $55(24.55)$ & $110(49.11)$ & $56(25.00)$ \\
\hline 5 & Work overload & $0(0.00)$ & $0(0.00)$ & $2(0.89)$ & $110(49.11)$ & $112(50.00)$ \\
\hline 6 & Salary Dissatisfaction & $0(0.00)$ & $0(0.00)$ & $1(0.45)$ & $1(0.45)$ & $222(99.11)$ \\
\hline 7 & Poor communication & $0(0.00)$ & $0(0.00)$ & $0(0.00)$ & $56(25.00)$ & $168(75.00)$ \\
\hline 8 & $\begin{array}{l}\text { personality differ- } \\
\text { ences }\end{array}$ & $0(0.00)$ & $0(0.00)$ & $96(42.86)$ & $72(32.14)$ & $56(25.00)$ \\
\hline 9 & Abuse of authority & $0(0.00)$ & $1(0.45)$ & $2(0.89)$ & $165(73.66)$ & $56(25.00)$ \\
\hline 10 & $\begin{array}{l}\text { Scarce resource al- } \\
\text { location }\end{array}$ & $0(0.00)$ & $0(0.00)$ & $5(2.23)$ & $163(72.77)$ & $56(25.00)$ \\
\hline 11 & Poor compensation & $0(0.00)$ & $2(0.89)$ & $4(1.79)$ & $161(71.88)$ & $57(25.45)$ \\
\hline 12 & $\begin{array}{l}\text { Performance apprais- } \\
\text { als }\end{array}$ & $0(0.00)$ & $0(0.00)$ & $3(1.34)$ & $109(48.66)$ & $112(50.00)$ \\
\hline 13 & Work interruptions & $0(0.00)$ & $0(0.00)$ & $4(1.79)$ & $52(23.21)$ & $16(75.00) 8$ \\
\hline 14 & Delayed promotion & $0(0.00)$ & $0(0.00)$ & $4(1.79)$ & $51(22.77)$ & $169(75.45)$ \\
\hline
\end{tabular}

Table 4 shows the response of the employees' perception assessment of effectiveness of the conflict management tools. The table shows that employees' preferences are the unions $(75 \%$ effective and $25 \%$ very effective), the HR department ( $74.5 \%$ effective, $22.7 \%$ very effective and $2.7 \%$ highly effective). Other tools such as joint consultation $(5.8 \%$ highly ineffective and $44.2 \%$ ineffective), dispute claims (25\% highly ineffective and 50\% ineffective), and arbitration (19\% highly ineffective, $55.8 \%$ ineffective) are not considered as effective. Since unions are involved in collective bargaining, the data also correlated with the assessment of effectiveness of the unions with $50 \%$ rating as effective, $49 \%$ very effective and $1 \%$ highly effective. The participatory goal setting and resignation have overwhelming preference as shown in the study data $(100 \%$ range between effective and highly effective). Confrontation and petitioning are considered somewhat effective responses. 
Tab. 4 - Frequency of responses to a research question of how effective the conflict management tools/systems are. Source: Field survey 2016

\begin{tabular}{|c|c|c|c|c|c|c|}
\hline \multicolumn{7}{|c|}{$\begin{array}{l}\text { Frequency distribution of effectiveness of } \\
\text { Total: } 224 \text { (100); Cummulative } \%: 100 \%\end{array}$} \\
\hline & Variables & $\begin{array}{l}\text { highly } \\
\text { ineffective }\end{array}$ & ineffective & effective & $\begin{array}{l}\text { very } \\
\text { effective }\end{array}$ & $\begin{array}{l}\text { highly } \\
\text { effective }\end{array}$ \\
\hline 1 & $\begin{array}{l}\text { Joint consultative } \\
\text { committees }\end{array}$ & $13(5.8)$ & $99(44.2)$ & $87(38.84)$ & $15(6.7)$ & $10(4.46)$ \\
\hline 2 & supervisors & $9(4.02)$ & $44(19.64)$ & $168(75.0)$ & $3(1.34)$ & $0(0)$ \\
\hline 3 & grievance procedure & $19(8.48)$ & $37(16.52)$ & $112(50.0)$ & $51(22.77)$ & $5(2.23)$ \\
\hline 4 & Unions & $0(0)$ & $0(0)$ & $168(75.0)$ & $56(25.0)$ & $0(0)$ \\
\hline 5 & HR Department & $0(0)$ & $0(0)$ & $167(74.55)$ & $51(22.77)$ & $6(2.68)$ \\
\hline 6 & Dispute claim & $56(25.0)$ & $112(50.0)$ & $45(20.09)$ & $11(4.91)$ & $0(0)$ \\
\hline 7 & arbitration & $43(19.20)$ & $125(55.8)$ & $56(25.0)$ & $0(0)$ & $0(0)$ \\
\hline 8 & avoidance & $0(0)$ & $1(0.45)$ & $110(49.11)$ & $112(50.0)$ & $1(0.45)$ \\
\hline 9 & $\begin{array}{l}\text { participation in goal } \\
\text { setting }\end{array}$ & $0(0)$ & $0(0)$ & $20(8.93)$ & $204(91.07)$ & $0(0)$ \\
\hline 10 & Collective bargaining & $0(0)$ & $0(0)$ & $112(50.0)$ & $110(49.11)$ & $2(0.89)$ \\
\hline 11 & confrontation & $0(0)$ & $56(25.0)$ & $112(50.0)$ & $56(25.0)$ & $0(0)$ \\
\hline 12 & compromise & $0(0)$ & $0(0)$ & $47(20.98)$ & 12154.02) & $56(25.0)$ \\
\hline 13 & Resignation & $0(0)$ & $0(0)$ & $135(60.27)$ & $68(36.36)$ & $21(9.38)$ \\
\hline 14 & Petitioning & 49 & $7(3.13)$ & $112(50.0)$ & $56(25.0)$ & $0(0)$ \\
\hline
\end{tabular}

Also, to on a follow up question of whether employees are encouraged to raise and discuss conflict with their supervisors, $16 \%$ responded [YES] and 84\% [NO], while $66 \%$ reported awareness of the conflict resolution machineries YES [66\%], NO [44\%].

Tab. 5 - Frequency of responses to a research question of what the likely behavioural responses to conflict by employees are. Source: Field survey 2016

Frequency distribution of behavioral response to conflict- $\mathrm{f}(\%)$

Total: 224 (100); Cummulative \%: 100\%

\begin{tabular}{|l|l|l|l|l|l|}
\hline & Variables & Never & seldom & $\begin{array}{l}\text { some of the } \\
\text { times }\end{array}$ & $\begin{array}{l}\text { most of the } \\
\text { times }\end{array}$ \\
\hline 1 & sabotage & $0(0)$ & $56(25.0)$ & $112(50.0)$ & $56(25.0)$ \\
\hline 2 & increase in waste level & $0(0)$ & $56(25.0)$ & $112(50.0)$ & $56(25.0)$ \\
\hline 3 & Absenteeism & $0(0)$ & $0(0)$ & $56(25.0)$ & $168(75.0)$ \\
\hline 4 & Uncoopertiveness & $0(0)$ & $0(0)$ & $56(25.0)$ & $168(75.0)$ \\
\hline 5 & in-fighting & $0(0)$ & $56(25.0)$ & $56(25.0)$ & $112(50.0)$ \\
\hline 6 & Productivity restriction & $0(0)$ & $2(0.89)$ & $60(26.79)$ & $162(72.32)$ \\
\hline
\end{tabular}




\begin{tabular}{|l|l|l|l|l|l|}
\hline 7 & Damaging org'nal reputation & $6(2.68)$ & $6(2.68)$ & $157(70.09)$ & $55(24.55)$ \\
\hline 8 & resignation & $1(0.45)$ & $57(25.45)$ & $109(48.66)$ & $57(25.45)$ \\
\hline 9 & Hostility & $3(1.34)$ & $58(25.89)$ & $111) 49.55)$ & $52(23.21)$ \\
\hline 10 & Lowering product quality & $1(0.45)$ & $7(3.13)$ & $109(48.66)$ & $107(47.77)$ \\
\hline 11 & Discouraging new applicants & $1(0.45)$ & $4(1.79)$ & $112(50.0)$ & $107(47.77)$ \\
\hline 12 & Stealing & $66(29.46)$ & $61(27.45)$ & $57(25.45)$ & $40(17.86)$ \\
\hline
\end{tabular}

The Levene's test in Table 6 on gender variability of intra-organizational conflict show that there are variations in the perception of sources of conflict between male and female employees in the sample and those differences are significant at statistical level. The female employees perceived a higher mean level of conflict than male employees for rejection of ideas (Mean= male 3.24, female 4.55, sig $\leq .02$ ), undefined work expectations (Mean= male 3.65, female 3.91, sig $\leq .01$ ), poor communication (Mean= male 3.65, female 3.91, sig $\leq .01$ ), personality differences (Mean $=$ male 3.12 , female 3.45 , sig $\leq .01)$ as well as those conflict manifesting from performance appraisal $($ Mean $=$ male 4.45, female 4.95, sig $\leq .01)$. The result also indicates that male employees are more likely than females to react to abuse of authority (Mean $=$ male 3.41, female 3.0, sig $\leq$ .01 ), allocation of resources (Mean $=$ male 3.82, female 3.0, sig $\leq .01)$, poor compensation (Mean $=$ male 4.88 , female 4.45 , sig $\leq .01$ ), and interruption in the work process (Mean $=$ male 3.82, female 2.92, sig $\leq .01)$.

Tab. 6 - Levene's Test of gender equality of conflict sources. Source: Study survey

\begin{tabular}{|c|c|c|c|c|c|c|c|}
\hline \multicolumn{8}{|c|}{$\begin{array}{l}\text { Group statistics of variation in the sources of conflcit between male and female gender in } \\
\text { the sample population }\end{array}$} \\
\hline \multirow{2}{*}{\multicolumn{2}{|c|}{ Gender }} & \multirow{3}{*}{$\frac{N}{136}$} & \multirow{3}{*}{$\begin{array}{l}\text { Mean } \\
3.53\end{array}$} & \multirow{3}{*}{\begin{tabular}{|l|}
$\begin{array}{l}\text { Std. De- } \\
\text { viation }\end{array}$ \\
.501 \\
\end{tabular}} & \multirow{3}{*}{$\begin{array}{l}\text { Std. Er- } \\
\text { ror Mean } \\
.043\end{array}$} & \multicolumn{2}{|c|}{ LEVENE'S TEST } \\
\hline & & & & & & \multirow{2}{*}{ F 230} & \multirow{2}{*}{$\begin{array}{ll}\text { Sig. } \\
.632\end{array}$} \\
\hline & Male & & & & & & \\
\hline Goal conflict & Female & 88 & 3.45 & .501 & .053 & & \\
\hline \multirow{2}{*}{$\begin{array}{l}\text { Rejection of } \\
\text { ideas }\end{array}$} & Male & 136 & 3.24 & .548 & .047 & 6.882 & 0.009 \\
\hline & Female & 88 & 4.55 & .501 & .053 & & \\
\hline \multirow{2}{*}{ unclear Tasks } & Male & 136 & 3.71 & .668 & .057 & 5.990 & 0.015 \\
\hline & Female & 88 & 4.45 & .501 & .053 & & \\
\hline \multirow{2}{*}{$\begin{array}{l}\text { Undefined } \\
\text { Work Expecta- } \\
\text { tions }\end{array}$} & Male & 136 & 3.65 & .683 & .059 & 130.241 & 0.632 \\
\hline & Female & 88 & 3.91 & 1.002 & .107 & & \\
\hline \multirow{2}{*}{ Work overload } & Male & 136 & 4.53 & .501 & .043 & .230 & .000 \\
\hline & Female & 88 & 4.45 & .501 & .053 & & \\
\hline \multirow{2}{*}{$\begin{array}{l}\text { Salary Dissatis- } \\
\text { faction }\end{array}$} & Male & 136 & 5.00 & $.000 \mathrm{a}$ & 0.000 & $\mathrm{a}$ & $\mathrm{a}$ \\
\hline & Female & 88 & 5.00 & $.000 \mathrm{a}$ & 0.000 & & \\
\hline \multirow{2}{*}{$\begin{array}{l}\text { Poor Commu- } \\
\text { nication }\end{array}$} & Male & 136 & 3.65 & .683 & .059 & 130.241 & 0.000 \\
\hline & Female & 88 & 3.91 & 1.002 & .107 & & \\
\hline
\end{tabular}




\begin{tabular}{|c|c|c|c|c|c|c|c|}
\hline \multirow{2}{*}{$\begin{array}{l}\text { Personality } \\
\text { differences }\end{array}$} & Male & 136 & 3.12 & .967 & .083 & 300.234 & 0.000 \\
\hline & Female & 88 & 3.45 & .501 & .053 & & \\
\hline \multirow{2}{*}{$\begin{array}{l}\text { Abuse of } \\
\text { authority }\end{array}$} & Male & 136 & 3.41 & .494 & .042 & 2713.333 & 0.000 \\
\hline & Female & 88 & 3.00 & 0.000 & 0.000 & & \\
\hline \multirow{2}{*}{$\begin{array}{l}\text { Scarce resourc- } \\
\text { es allocation }\end{array}$} & Male & 136 & 3.82 & .988 & .085 & 2713.333 & 0.000 \\
\hline & Female & 88 & 3.00 & 0.000 & 0.000 & & \\
\hline \multirow{2}{*}{$\begin{array}{l}\text { Poor compen- } \\
\text { sation }\end{array}$} & Male & 136 & 4.88 & .323 & .028 & 113.499 & 0.000 \\
\hline & Female & 88 & 4.45 & .565 & .060 & & \\
\hline \multirow{2}{*}{$\begin{array}{l}\text { Performance } \\
\text { Appraisals }\end{array}$} & Male & 136 & 4.59 & .494 & .042 & 448.554 & 0.000 \\
\hline & Female & 88 & 4.95 & .209 & .022 & & \\
\hline \multirow{2}{*}{$\begin{array}{l}\text { Delayed Pro- } \\
\text { motion }\end{array}$} & Male & 136 & 4.47 & .501 & .043 & 1.939 & 0.000 \\
\hline & Female & 88 & 4.89 & 4.156 & .443 & & \\
\hline \multirow{2}{*}{$\begin{array}{l}\text { Work Interrup- } \\
\text { tion }\end{array}$} & Male & 136 & 3.82 & .988 & .085 & 752.627 & 0.000 \\
\hline & Female & 88 & 2.92 & .312 & .033 & & \\
\hline
\end{tabular}

***a. $\mathrm{t}$ cannot be computed because the standard deviations of both groups are 0 .

Tab. 7 - Test result of behavioural manifestation of conflict between male and female employees. Source: Study survey

Test result of behavioural manifestation of conflict between male and female employees. Source.

\begin{tabular}{|c|c|c|c|c|c|c|c|}
\hline \multirow{2}{*}{\multicolumn{2}{|c|}{$\begin{array}{l}\text { Behavioral Reactions by } \\
\text { Gender }\end{array}$}} & \multirow{3}{*}{$\begin{array}{l}\mathrm{N} \\
136\end{array}$} & \multirow{3}{*}{$\begin{array}{l}\text { Mean } \\
3.35 \\
\end{array}$} & \multirow{3}{*}{$\begin{array}{l}\text { Std. De- } \\
\text { viation } \\
.590\end{array}$} & \multirow{3}{*}{$\begin{array}{l}\text { Std. Er- } \\
\text { ror Mean } \\
.051\end{array}$} & \multicolumn{2}{|c|}{ LEVENE'S TEST } \\
\hline & & & & & & \multirow{2}{*}{$\begin{array}{l}\mathrm{F} \\
1.884\end{array}$} & \multirow{2}{*}{$\begin{array}{l}\text { Sig. } \\
.171\end{array}$} \\
\hline \multirow{2}{*}{ Result to Sabotage } & Male & & & & & & \\
\hline & Female & 88 & 2.45 & .501 & .053 & & \\
\hline \multirow{2}{*}{$\begin{array}{l}\text { Resultt to WasteIn- } \\
\text { crease }\end{array}$} & Male & 136 & 3.35 & .590 & .051 & 1.884 & .171 \\
\hline & Female & 88 & 2.45 & .501 & .053 & & \\
\hline \multirow{2}{*}{$\begin{array}{l}\text { Result to Absentee- } \\
\text { ism }\end{array}$} & Male & 136 & 3.59 & .494 & .042 & 2713.333 & .000 \\
\hline & Female & 88 & 4.00 & 0.000 & 0.000 & & \\
\hline \multirow{2}{*}{$\begin{array}{l}\text { Result to Uncoop- } \\
\text { erativeness }\end{array}$} & Male & 136 & 3.94 & .236 & .020 & 291.181 & .000 \\
\hline & Female & 88 & 3.45 & .501 & .053 & & \\
\hline \multirow{2}{*}{$\begin{array}{l}\text { Result to in-fight- } \\
\text { ing }\end{array}$} & Male & 136 & 3.76 & .548 & .047 & 6.882 & .009 \\
\hline & Female & 88 & 2.45 & .501 & .053 & & \\
\hline \multirow{2}{*}{$\begin{array}{l}\text { Result toLowering } \\
\text { Output }\end{array}$} & Male & 136 & 3.53 & .530 & .045 & 1404.147 & .000 \\
\hline & Female & 88 & 4.00 & 0.000 & 0.000 & & \\
\hline \multirow{2}{*}{$\begin{array}{l}\text { Result to Damag- } \\
\text { ing Organization } \\
\text { Image }\end{array}$} & Male & 136 & 2.99 & .584 & .050 & 17.213 & .000 \\
\hline & Female & 88 & 3.44 & .500 & .053 & & \\
\hline
\end{tabular}




\begin{tabular}{|l|l|l|l|l|l|l|l|}
\hline \multirow{2}{*}{$\begin{array}{l}\text { Result to Resigna- } \\
\text { tion }\end{array}$} & Male & 136 & 2.69 & .694 & .060 & 8.955 & .003 \\
\cline { 2 - 9 } & Female & 88 & 3.45 & .501 & .053 & & \\
\hline \multirow{2}{*}{ Result to Hostility } & Male & 136 & 3.21 & .751 & .064 & 5.605 & .019 \\
\cline { 2 - 9 } & Female & 88 & 2.55 & .501 & .053 & & \\
\hline \multirow{2}{*}{$\begin{array}{l}\text { Result to Lowering } \\
\text { Product Quality }\end{array}$} & Male & 136 & 3.37 & .618 & .053 & 3.044 & .082 \\
\cline { 2 - 9 } & Female & 88 & 3.55 & .501 & .053 & & \\
\hline \multirow{3}{*}{$\begin{array}{l}\text { Result to Discour- } \\
\text { aging Applicants }\end{array}$} & Male & 136 & 3.39 & .586 & .050 & 1.600 & .207 \\
\cline { 2 - 9 } & Female & 88 & 3.55 & .501 & .053 & & .000 \\
\hline \multirow{2}{*}{\begin{tabular}{l} 
Result to Stealing \\
\cline { 2 - 9 }
\end{tabular}} & Male & 136 & 2.88 & .985 & .084 & 16.992 & \\
\hline
\end{tabular}

Furthermore, from Table 7 above, we found out that there are significant behavioural differences in the reaction of employees to conflict within their organisations which found expression in male employees who are more likely to adopt uncooperativeness attitude than female (Mean = male 3.94, female 3.45, sig $\leq .01)$ engaged in in-fighting (Mean = male 3.76, female 2.45, $\leq .01)$, manifest hostile attitude (Mean $=$ male 3.21, female 2.25, sign $\leq .02)$ while engaging in stealing $($ Mean $=$ male 2.88, female 1.45, sig $\leq .01)$. Female employees will, however, more than male likely adopt absenteeism (Mean $=$ male 3.59, female 4.0, sig $\leq .01)$, engage in output restriction $($ Mean $=$ male 3.53, female 4.0, sig $\leq .01)$, also speak and project negatively about their organisations $($ Mean $=$ male 2.49, female 3.44, sig $\leq .01)$ and resign their appointments (Mean = male 2.69, female 3.45, sig. $\leq .01)$.

\section{DISCUSSION}

A key aspect of managing people to achieve a vibrant SME subsector in the complex social, economic and political operational environments remains to be a very challenging managerial function in Nigeria. While policy emphasis and research suggest that resource-based challenges hinder performance of the SMEs, the setting up of Nigeria Industrial Development Bank and several Central Bank initiatives have not been very successful across board. This study is not questioning the validity of the resource-based claims but significantly found that intra-organizational conflicts play significant roles in the underperformance analysis of the SMEs. The extent of the impact depends greatly on the process of managing these challenges in the light of the procedures performed by the managers (Mushref, 2002). Identifying conflict processes, their manifestation and impact become imperative for managers of SMEs where resources and performance are always major concerns. Both managers and researchers have been closing their eyes to the possibility of intra-organizational conflict as a major challenge to the SMEs and their preponderance may become a significant impact than ordinarily acknowledged. This study found that not only do the conflicts occur in the SMEs but they significantly impact on performance. The identified conflict sources include work overload $(50 \%)$, salary dissatisfaction $(99 \%)$, poor communication $(75 \%)$, performance appraisal $(50 \%)$, work interruption (75\%) and slow promotion (75\%); see Table 2 for details. 
Furthermore, the data show that employees most of the times exhibit negative behaviours as a reaction to conflict in the form of absenteeism (75\%), uncooperativeness $(75 \%)$ and productivity restriction $(72 \%)$. They also sometimes result in sabotage $(50 \%)$, increase in waste level $(50 \%)$ and batter organizational image (75\%), which discourage new applicants $(50 \%)$ as well as cause resignation and hostility [see Table 5]. The study also seeks to establish whether there are gender variations in both sources of conflict and employees' behavioural reactions. To assess whether employees are familiar with conflict management procedures and machineries, $66 \%$ reported positively but only $15 \%$ reported that they are encouraged to openly discuss conflict with their managers, which may suggest high incidents of conflict suppression in the organisations.

This study showed that intra-organisational conflict is not a simple, single phenomenon but a cocktail of behaviours that find expression in many contexts while some are 'substantive and others are affective'. The substantive conflict derived from the structure of work and work expectations such as the goal conflict, resource allocation, work overload, poorly defined work performance expectations, compensation issues, disagreement over performance appraisals, the authority relationship and work design, particularly the interdependency of work that makes interruption possible. The affective conflict is derived from interpersonal relationship and emotional responses to conflict incidents such as poor communication, resentment of others and those we may categorise as relative deprivation, i.e. promotion and appraisal issues. We understand first that conflict is an important organizational interface even in the SMEs calls for a critical attention by managers and entrepreneurs in the sector to first understand their nature of the conflict within their environment and the manifestation of employees' behaviour and how they impact performance and productivity.

Hocker \& Wilmot (1995) discuss several methods of ending conflicts: (1) avoidance, (2) conquest and (3) procedural resolution of some kind, including reconciliation and/or compromise and/or award. Avoidance of conflict often leads to intensified hostility and may later cause greater problems for the group. The report shows overwhelming perception of conflict suppression with only $16 \%$ reporting freedom to openly discuss conflict with their supervisors. Therefore, one of the first steps in conflict management is to recognize that a conflict situation exists, because ignoring its existence cannot make it disappear on its own. The effectiveness of the machineries for managing the conflicts beg the question as this study shows that only $10 \%$ of employees perceived joint consultation to be very effective and $1.3 \%$ for their supervisors, arbitration was considered highly ineffective $(75 \%)$. It seems that they consider the unions and HR department's intervention as effective means of resolving conflict. It is probably because of a poor perception of the effectiveness of those institutional conflict management tools and systems that employees reported high favourable for self-help approaches such as avoidance, confrontation and quality compromise with the option of resignations as being prominent amongst the choices (see Table 4).

Furthermore, the study data shows that gender plays a significant role in both the perception and behavioural responses to conflict in the sample population. The male gender manifests more competitive behaviours than the female gender as a source of intra-organizational conflict at statistical level of significance such as the variances in the resource allocation, abuse of authority, compensation disputes and interruption of the workflow process. The data also suggest that male employees will more likely engage uncooperative behaviours, infighting and hostility while 
female employees more than males will engage in avoidance behaviours demonstrated in absenteeism, output restriction, resignation and they will talk negatively about their organisation (see Table 6 and 7 above). Contrary to the suggestion of Antonioni (1998) who stated that gender in general had little relationship with the variance of conflict-management style, the study found gender-based differences at statistical level of significance in the perception and behavioural manifestation of intra-organisational conflict but supported Brewer et al. (2002) who mentioned that female employees are more likely than male to adopt avoiding conflict-handling style.

\section{Limitations}

The generalizability of the results is limited by a relatively small sample of the study to a geographic area with a relative homogeneous cultural affinity. As such, the impact of cultural variances on conflict behaviour in a larger and more diverse population could not be ascertained. Also, the study did not control the impact of age and academic differences, which may affect the ways a conflict situation is processed and behavioural responses too.

\section{CONCLUSION}

This study observed that conflict within organisations takes different forms while offering a number of opinions on what constitutes a conflict. It is generally seen as deriving its sources from competition amongst units or groups, goal incompatibility, competition for limited resources, work overload and interruption and personality differences [could also include cultural or value differences] as well as those that emanates from compensation and performance appraisals amongst a list of other sources. The study shows that conflict behaviour is manifested in various forms in the selected organisations and that a significant variation in this behaviour occurs at statistical level of significance between the male and female genders. The study also found that while there are numbers of conflicts, behavioural outcomes (i.e., as shown in Table 5) that most often exist involve the prevalence of performance restriction and causing damage to the image of the organisation. A major implication of the findings is that whereas previous studies have confirmed the resource-based operational challenges in the SMEs, poor management of the scarce resources such as manifest in quality and output restrictions as suggested in this study becomes significantly a compounding effect on performance and competitiveness.

Whereas Mughal \& Khan (2013) found that the most often used means of managing conflict among the managers and employees in Pakistani organizations are integrating, dominating and compromising, the efficacy of the existing conflict management tools in the study sample of SMEs in Nigeria is questionable as shown in this study report in Figure 4. The unions, collective bargaining and resignation are perceived to be more effective options followed by the role of HRM in terms of assessment of effectiveness than the supervisors who have primary responsibilities for managing their teams productively. This result may be skewed by the nature of SMEs management in the country, some of which do not create effective structures for employees' expression of conflict that may have likely propel the significance of the unions, i.e. where they are recognised and seen to be more effective in terms of representation and conflict management. Organisations in more advanced economies are employing the alternative dispute resolution (ADR) methods such as arbitration which the study result found to be considered highly inef- 
fective. The implications of the finding on human resource management are self-evident in the view of the disruptive nature of conflict on organisational performance and the reported ineffectiveness of most of the common conflict management tools included in the study. The roles of the joint consultative committee, supervisor and the grievance procedure have been recognized as the organisational system for conflict management but this study queries their effectiveness. Poor conflict management systems and tools may contribute to performance problems in the organisations as suggested by this study data. Especially with the reported manifestation of productivity restriction, image battering and discouraging potential applicants. These outcomes negate the efforts of human resource managers to attract, motivate and retain high-potential employees in the SMEs.

Drawing on the conclusions of this study, it is therefore imperative for HRM to improve the existing systems for conflict management and build into the system effective machineries for minimising and/or managing conflict. Goals should be clearly defined and the participation of the employees in setting goals is encouraged while adopting some systems of conflict preventive measures such as open communication with the objectives of encouraging compromise, fair reward and performance management system that are likely to minimize intra-organizational conflict. Boulding (1962) states that the biggest challenge in developing the institutions of conflict administration in organisation is the development of an effective action plan to identify conflicts at its initial stage. This is entirely the responsibility of managers and supervisors with HRM providing leadership and guidance. Conflict situations are frequently allowed to develop to almost unmanageable proportions before anything is done about it and by this time it is often too late to resolve by peaceable and procedural means. Knippen \& Green (1999) recommend (and we agree with and adopt the position in this study) that the processes to manage conflict should include an active participation by parties involved describing the conflict situation to the other person.

Finally, while we realise that managers are busy people, the myriad of contextual organisational challenges affecting the performance and survival of the SMEs make it imperative that they should devote sufficient time and attention to the management of a negative conflict. For example, in a global competitive environment, organisations may not be able to afford to lose productive experienced employees nor suffer an induced poor product quality arising from unresolved internal conflicts. Every manager should therefore be sufficiently trained (Ogunbayo, 2013) so as to become skilful in conflict management, as lack of such knowledge may have accounted for the reported low percentage of open conflict discussions and likely high incidence of conflict suppression. Given that conflict is an enduring part of organisational life, the challenge to HRM therefore is the design of systems that minimizes the negative impacts of conflict on performance and employee productivity and to develop adequate managerial skills and capacity to encourage open discussion about conflict and ability to effectively resolve them. Such system as recommended here may include defined policies and procedures, organisational health surveys, regular joint consultative meetings and open communication while sustaining employees' confidence in the system through openness and fairness in the adjudication of conflict resolutions.

Also, the HRM infrastructures in the SMEs should be enhanced in terms of skills and tools to support effective performance management system given that performance appraisal remains one of the critical conflict subject in the study sample. Regular training of supervisors and 
employees in the performance appraisal tools, assessment and reviews are likely to reduce the incidence of conflict as well as equipping the supervisors with conflict resolution skills, thereby raising the confidence level of employees' perception of supervisory conflict management skills. HRM would also conduct a regular organizational health audit in the SMEs which are likely able to reveal a tacit conflict before they manifest in more negative outcomes such as expressed in this study, which could become detrimental to the performance and effectiveness of the SMEs. A major focus for further research is more likely to include the impact of organizational characteristics in the SMEs, i.e. leadership, ownership and culture among others, on manifestation of conflict. The increase in foreign direct investment (FDI) in SMEs, particularly from Chinese and other Asian companies and individuals in Nigeria, support a call for such a study which may reveal different dimensions and prevalence of other conflict behaviours and their consequences on performance and profitability.

In closing, this study has raised awareness to the preponderance of conflict in the SMEs and reveals that it could be a significant source of performance challenges faced by the subsector. HRM process enhancements are required to improve the effectiveness of conflict management machineries, and managers are to be encouraged to be more open to conflict discussion arising from members of their team.

\section{References}

1. Adomi, E. E. \& Anie, S. O. (2005). Conflict Management in Nigerian University Libraries. Journal of Library Management, 27(8), 520-530. https://doi.org/10.1108/01435120610686098.

2. Ahmedova, S. (2015). Factors for Increasing the Competitiveness of Small and MediumSized Enterprises (SMEs) In Bulgaria,.Procedia - Social and Behavioral Sciences 195, 1104-1112, https://doi.org/10.1016/j.sbspro.2015.06.155.

3. Alper, S., Tjosvold, D \& Law, K. S. (2000). Conflict Management, Efficacy, and Performance in Organizational Teams. Personnel Psychology 53 (3), 625-642. https://doi. org/10.1111/j.1744-6570.2000.tb00216.x.

4. Antonioni, D. (1998). Relationship Between the Big Five Personality Factors and Conflict Management Styles. International Journal of Conflict Management, 9(4), 336-355. https://doi. org/10.1108/eb022814.

5. Awan, A. G., \& Saeed, S. (2015). Conflict Management and Organizational Performance: A Case Study of Askari Bank Ltd. Research Journal of Finance and Accounting, 6(11), 88-102.

6. Bankole, A. R. (2007). An Evaluation of the Statutory Machinery for Industrial Conflict Resolution in Nigeria. LASU Journal of Social Science, 6(1/2), 36-46.

7. Bannock, G. (2005). The Economics and Management of Small Business: An International Perspective. New York: Routledge. New York.

8. Boulding, K. B. (1962). Conflict and Defence. New York: Harper \& Row.

9. Brewer, N., Mitchell, P., \& Weber, N. (2002). Gender Role, Organisational Status, and Conflict Management Styles. The International Journal of Conflict Management, 13(1), 78-94.

10. Collins, R. (1994). The Conflict Tradition. New York: Oxford University Press. 
11. Cosie, R. A., \& Rose, R. L. (1977). Cognitive Conflict and Goal Conflict Effects on Task Performance. Organizational Behaviour and Human Performance, 9(2), 378-391. https://doi. org/10.1016/0030-5073(77)90071-x.

12. DeDrue, C. K. W. \& Weingart, L. R. (2003). Task Versus Relationship Conflict, Team Performance and Team Member Satisfaction: A Meta Analysis. Journal of Applied Psychology, 88 (4), 741-749. https://doi.org/10.1037/0021-9010.88.4.741.

13. Druckman, D., \& Zechmeister, K. (1973). Conflict of Interest and Value Dissensus: Propositions in the Sociology of Conflict. Human Relations, 26(4), 449-466. https://doi. org $/ 10.1177 / 001872677302600403$.

14. Fisher, N. (2010). A Better Way to Manage Conflict. Political Quarterly, 81 (3), 428-430. https://doi.org/10.1111/j.1467-923x.2010.02103.x.

15. Gayle, B. M., Preiss, R. W. \& Allen, M. (1994). Gender Differences and the Use of Conflict Strategies. Connecticut: Beigm \& Garvey.

16. Henry O. (2009). Organizational Conflict and its Effects on Organizational Performance. Research Journal of Business Management, 3 (1), 16-24. https://doi.org/10.3923/rjbm.2009.16.24.

17. Hocker, J. L. \& Wilmot, J. J. (1995). Interpersonal Conflict (4th Edition). USA: The McGrawHill Companies Inc.

18. Hotepo, O. M., Asokere, S. S., Abdul-Azeez, A., \& Ajemunigbohun, S. A. (2010). Empirical Study of the Effect of Conflict on Organizational Performance in Nigeria. Business and Economics Journal, (15), 1-9.

19. Jehn, K. (1995). A Multi-Method Examination of the Benefits and Detriments of Intra-Group Conflict. Administrative Science Quarterly, 40(2), 256-282. https://doi. org $/ 10.2307 / 2393638$.

20. Jones, G. R., Gorge, J. M., \& Hill, C. W. L. (2000). Contemporary Management. Boston: MA. (2nd Edition), McGraw-Hill.

21. Knippen, J. T., \& Green, T. B. (1999). Handling Conflicts. Journal of Workplace Learning, 11(1), 27-32, https://doi.org/10.1108/13665629910250924.

22. Kozan, M. K. (1997). Culture and Conflict Management: A Theoretical Framework. The International Journal of Conflict Management 8(4), 338-360. https://doi.org/10.1108/eb022801.

23. Kuhn, T. \& Poole, M. S. (2000). Do Conflict Management Styles Affect Group Decision Making?. Human Communication Research 26(4), 558-590. https://doi.org/10.1111/j.14682958.2000.tb00769.x.

24. LaFrance, M., Brownell, H. \& Hahn. E. (1997). Interpersonal Verbs, Gender and Implicit Causality. Social Psychology Quarterly 60(2), 138-152. https://doi.org/10.2307/2787101.

25. Lovelace, K. Shapiro, D. L. \& Weingart. L. R. (2001). Maximizing Cross-Functional New Product Teams' Innovativeness and Constraints Adherence: A Conflict Communication Perspective. Academy of Management Journal 44(4), 779-793 https://doi.org/10.2307/3069415.

26. Mitchell, R. C \& Mitchel R. R. (1984). Constructive Management of Conflict in Groups. The Journal for Specialists in Group Work 9(3), 137-144, https://doi.org/10.1080/019339284084 12520 . 
27. Mughal, M. R. \& Khan, M. (2013). Impact of Conflict and Conflict Management on Organisational Performance. International Journal of Modern Business Issues of Global Market (IJMBIGM).

28. Mushref, M. A. (2002). Managing Conflict in a Changing Environment. Management Services Journal, 46(11), 8-19.

29. Nightingale, C. (1974). Conflict Resolution Skills. No details.

30. Ogunbayo, O. (2013). Conflict Management in Nigerian Construction Industry: Project Managers' view. Journal of Emerging Trends in Economics and Management Sciences, 4(2), 140-155.

31. Omoluabi, P. F. (2001). Principles and processes of conflictology. Ife Psychologia: An International Journal, 9(3), 1-13. https://doi.org/10.4314/ifep.v9i3.23627.

32. Pelled, L. H., Eisenhardt, K. M., \& Xin, K. R. (1999). Exploring the Black Box: An Analysis of Work Group Diversity, Conflict, and Performance. Administrative Science Quarterly, 44 (1), 1-28.

33. Rahim, M. A. (2002). Toward a Theory of Managing Organizational Conflict. The International Journal of Conflict Management 13(3), 206-235. https://dx.doi.org/10.1108/ eb022874.

34. Robert, T (2005). Coaching Managers Through Their Conflicts. Management Services, 49(4), $161-72$.

35. Rössel, J. (2013). Conflict Theory, (details not available). retrieved from http://suz.uzh. ch/roessel_en.html. https://doi.org/10.1093/OBO/9780199756384-0035.

36. Taylor, A. \& Miller, J. B. (1994). Conflict and Gender. New Jessy: Hampton Press.

37. Tinsley. C. H. (2001). How Negotiators Get to Yes: Predicting the Constellation of Strategies Used Across Cultures to Negotiate Conflict. Journal of Applied Psychology, 86(4), 583-593, https://doi.org/10.1037//0021-9010.86.4.583.

\section{Contact information}

Dr. Samuel Remi

Department of Employment Relations and Human Resource Management

Faculty of Business Administration,

University of Lagos, Akoka, Lagos

Nigeria

E-mail:remi.samuel@yahoo.com 